\title{
Utilization of Fertilizers for Improving The Process Rate of Organic Material Degradation in Anaerobic Reactor
}

\author{
A.A. Asmara ${ }^{1}$, A. Soegianto ${ }^{1}$, T.W.L.C. Putranto ${ }^{1}$, A. Hairul $^{1}$, and N.I. Oktavitri ${ }^{1}$
}

\begin{abstract}
This study aimed to assess utilization of fertilizers as nutrient in the anaerobic reactor. Nutrient is one important characteristic of waste for the treatment. Nutrient is required for the growth and reproduction process of microorganisms which involved in the anaerobic process. The wastewater used in this research is tofu wastewater. Gandasil B fertilizer has $N 6$ mg/l and P $20 \mathrm{mg} / \mathrm{l}$. While for Gandasil D fertilizer has $N 20 \mathrm{mg} / \mathrm{l}$ and P 15mg/l. Anaerobic reactor has $1000 \mathrm{ml}$ of capacity which contain $600 \mathrm{ml}$ of wastewater, $100 \mathrm{ml}$ of liquid fertilizer, and $300 \mathrm{ml}$ of space blank. Anerobic reactor observed for 14 days with 5 observed parameters. Those parameters are TSS, VSS, COD, N, and P. After 14 days, added of Gandasil B fertilizer decreased the concentration of TSS, VSS, COD, $N$, and $P$ amounted to 57,56\%, 26,84\%, 80,08\%, 96,75\%, and 93,18\%. compared to the 0th day. While the addition of Gandasil $D$ fertilizer decreased the parameters amounted to $3,48 \%, 6,21 \%, 86,72 \%, 58,10 \%$, and $\mathbf{9 0 , 7 8 \%}$. In conclusion, Gandasil B fertilizer in the anaerobic reactor improves the rate of organic material degradation more effectively than Gandasil D fertilizer.
\end{abstract}

Keywords-Anaerobic reactor, COD, fertilizer, N, nutrient, P, TSS, VSS.

\section{INTRODUCTION}

$\mathrm{T}$ ofu industry is one of the household scale industries which produces food everyday. Tofu industry can be found in almost every city in Indonesia. Tofu industry has untreated wastewater characteristic in environment. According to Romli [1], the process of tofu production produces liquid wastewater in large quantity, average of total liquid wastewater from tofu industry, per kilogram of soybeans was used produces $17 \pm 3 \mathrm{~L}$ the liquid wastewater. It has the potential to cause water pollution from tofu liquid wastewater.

Liquid wastewater of tofu has the characteristics of high yield organic. Tofu liquid wastewater containing large amounts of carbohydrates, proteins, and fats. Protein is the largest organic matter which contained in the tofu wastewater. According Myrasandri [2], the characteristics of tofu liquid wastewater consists of organic pollutants with a high value, so required an efficient and inexpensive cost of wastewater treatment for these.

Anaerobic reactor is one type of wastewater treatment that have high organic matter content. Anaerobic system is an economical and efficient system to solve the problem of industry waste. Anaerobic reactor has several advantages, simple, energy efficient, produce less sludge, and easy to operate [3]. The advantages of anaerobic reactor suitable for tofu wastewater is known of household scale industry. Simple processing and low cost required for the continuity these industry.

In the anaerobic reactor, anaerobic microorganisms is involved in the degradation process of organic matter. Anaerobic microorganisms grow and transform the organic material in the wastewater become carbon dioxide and methane gasses [4]. One of important characteristics in the processing of wastewater is nutrients required, especially inorganic nutrients.

${ }^{1}$ A.A. Asmara, A. Soegianto, T.W.L.C. Putranto, A. Hairul, and N.I. Oktavitri are with Departement of Biology, Faculty of Environmental Sains and Technology, Universitas Airlangga, Surabaya, Indonesia. Email: nur_i_d_o@yahoo.com.
Inorganic nutrients required for the growth of microorganisms, although the required is less nutrients. Nitrogen $(\mathrm{N})$ and phosphorus $(\mathrm{P})$ is one of the inorganic nutrients required for degradation process of organic material in the wastewater. According to Maier [5] in Ammary [6], the microorganism which involved in the organic removal process from wastewater necessary $\mathrm{N}$ and $\mathrm{P}$ for its growth and reproduction. Microorganism necessary $\mathrm{N}$ for composing protein, cell wall components, and nucleid acid.

According to Lettinga [7], most of the biodegradable organic matter in the wastewater is converted into another important product, such as biogas, up to $70-90 \%$ are removed from liquid phase become gaseous form. According Bagus [8], it is known that the process of wastewater treatment in anaerobic system can decrease of Biochemical Oxygen Demand (BOD) up to 70-80\% and COD (Chemical Oxygen Demand) up to 60\%. The statement reinforced by Nayono [9], that some studies from several countries reported that the anaerobic treatment have satisfactory success for domestic and industrial wastewater treatment. The BOD and COD could descrased up to $70-90 \%$.

Fertilizer is a substance contains certain nutrients that are commonly given to nourish soil and plants. Nutrients contained in fertilizers such us nitrate, phosphate, magnesium, potassium, and etc. Fertilizer in measured doses can give expected nutritional needs. Fertilizers are often used as an additive matter in the wastewater treatment process. According Paramita [10], the waste is added NPK fertilizer and urea fertilizer with a certain percentage of volume the waste. The purpose of NPK fertilizer and urea fertilizer is used as activation of naturally microorganisms in the first inoculum of septic tank.

Several studies which use the fertilizers as a nutrient for optimizing wastewater treatment process, ammonium nitrate (as N source) and SP36 (as a source of phosphate) is able to decrease the COD up to $85,15 \%$ [11]. The use of urea as a source of $\mathrm{N}$ and $\mathrm{P}$ K2HPO3 as the source is able to decrease the COD up to $90 \%$ the COD and the TSS (Total Suspended Solid) up to 91\% [12]. Nutrition 
of urea which have N $46 \%$ and Tri Super Phosphate (TSP) which have $\mathrm{P} 46 \%$ were able to decrease of nitrates from simulated radioactive waste liquid which contain nitrit acid from $25000 \mathrm{ppm}$ to 8,44 ppm during 464 hour period [13]. Nutrition of urea and TSP can decrease the COD from waste detergent with levels 1496 $\mathrm{mg} / \mathrm{L}$ to $10 \mathrm{mg} / \mathrm{L}$ during 106 hours [14].

Fertilizers that contain the elements $\mathrm{N}$ and $\mathrm{P}$ in this study added to the wastewater treatment process that use anaerobic reactor. The purpose of this research is investigated how effective the used of fertilizers to removal organic matter which contained in the wastewater based on the TSS (Total Suspended Solid), the VSS (Volatile Suspended Solid), the COD (Chemical Oxygen Demand), the N (nitrate), and the P (Phosphate) parameters were monitored for 14 days.

\section{METHOD}

Anaerobic batch reactor used in this study has a volume of $1000 \mathrm{ml}$ which tofu wastewater . The reactor consist of $600 \mathrm{ml}$ tofu wastewater, $100 \mathrm{ml}$ liquid fertilizer, and $300 \mathrm{ml}$ of empty space. Anaerobic batch reactors that used are 3 pieces. Anaerobic batch reactor made from plastic bottle with the lid, plastic hose about $\pm 50 \mathrm{~cm}$ and $\pm 1 \mathrm{~cm}$ in diameter. While the materials used in this study is a tofu wastewater, aquadest, and Gandasil B and Gandasil D.

Tofu wastewater put in $600 \mathrm{ml}$ of reactor. Gandasil B and Gandasil D, respectively $10 \mathrm{~g}$ diluted with $100 \mathrm{ml}$ of aquadest. The liquid fertilizer then poured into the reactor. The reactor was closed use a cap that drilled first and plugged it with a plastic hose. The parameters which measured in this study are the TSS, VSS, COD, N, and $\mathrm{P}$. The parameters measured at 0-day, and 14th day. Then the results of measurements be madea chart which describe of the value removal between 0-day and 14th day. In this study to analyze the parameters refers to the method of water (Alaerts and Santika, 1987).

Figure 1 is some pictures which show the process of this research and the step of procedure this research shown in the Figure 2

\section{RESULT AND DISCUSSION}

This is the result of study which observed during 14 days which show up in Table 1 . This research using batch reactor to determine the ability to decrease the degradation of organic material in the waste using the potential of endogenous bacteria in the waste. Batch reactors are also used to produce products, such as gasses. Batch reactor have a closed system enable there is anaerobic processes in it. Excess anaerobic processes in batch reactors can decrease high organic matter in the wastewater, so that the volume of reactor used smaller [9] It is appropriate for the wastewater in this study.

Fertilizer is a substance which can provide inorganic nutrients for the microorganisms in the process. Gandasil fertilizer is one of the many types of fertilizers used by farmers and often recommended by nutrition experts because it contains specific nutrients $\mathrm{N}$ and $\mathrm{P}$ which required their distribution [15]. Nutrients contained in Gandasil B is dominated P content about $20 \mathrm{mg} / \mathrm{l}$ compared to its $\mathrm{N}$ content. Other nutrients such as 6 $\mathrm{mg} / \mathrm{lnitrogen}, 30 \mathrm{mg} / \mathrm{l}$ potassium, and $3 \mathrm{mg} / \mathrm{l}$ magnesium. Fertilizer N contained in Gandasil D is dominated about of $20 \mathrm{mg} / \mathrm{l}$. Other nutrients such as $15 \mathrm{mg} / \mathrm{l}$ phosphate, $15 \mathrm{mg} / \mathrm{l}$ potassium, and $1 \mathrm{mg} / \mathrm{l}$ magnesium. The other compound elements such as Magnesium (Mn), Boron (B), Copper $(\mathrm{Cu})$, Zinc $(\mathrm{Zn})$ is the percentage of nutrients are not described in the product information beside the major nutrients, $\mathrm{N}$ and $\mathrm{P}$ [15].

Seen from the analysis of the parameters in this study with the addition of fertilizer as a nutrient, the decreasing process some parameters better than the control which not added anything. After 14 days, TSS levels decreased control up to 33,72\%, while the use of Gandasil B fertilizers can reduce TSS up to 57,56\%. COD levels decreased control up to $80,08 \%$, while the use of Gandasil D fertilizers can reduce the COD up to $86,72 \%$. $\mathrm{N}$ levels decreased control up to $92.82 \%$, while the use of Gandasil B fertilizers can reduce nitrate up to $96,75 \%$. P control levels decreased up to $31,97 \%$, while that using Gandasil B and D fertilizers, P parameter can decrease amount to $93,18 \%$ and $90,78 \%$. Beside that after 14 days, uses of Gandasil B fertilizer can decrease the concentration of TSS, VSS, COD, $\mathrm{N}$ and $\mathrm{P}$ amounted to 57,56\%, 26,84\%, 80,08\%, 96,75\%, 93,18\%. While uses Gandasil D fertilizer can decrease the concentration of TSS, VSS, COD, $\mathrm{N}$ and $\mathrm{P}$ amounted to 3,48\%, 6,21\%, $86,72 \%, 58,10 \%, 90,78 \%$.

The differences decreased of the parameters between uses of Gandasil B and Gandasil D fertilizer is thought to relate the ability of microorganisms to use available nutrients. It is also influenced by the differences other nutrients content in Gandasil fertilizer. Endogenous microorganisms in the waste have a different response to the presence of other nutrients in the Gandasil fertilizer. As the elements of $\mathrm{K}$ (Kalium) which serves to provide a supply of carbohydrates, it is C (carbon element) in GandasilB fertilizers higher than $\mathrm{N}$ and $\mathrm{P}$ elements. It appear in the process of degradable organic material such as carbon as evidenced by the value of COD. The Gandasil D Fertilizer is more effective than Gandasil B fertilizer. The existence of optimal nutrition too can disrupt the degradation process, which reduced the ability of microorganisms.

The addition of Gandasil fertilizer look more effectively reduce levels of organic material in the waste compared to control which not added anything. This is because the nutrients $\mathrm{N}$ and $\mathrm{P}$ are available a few number in the wastewater, so that the inorganic nutrients must be added from outside the system batch reactor. $\mathrm{N}$ and $\mathrm{P}$ also are steadily decreasing in the process of wastewater degradation which uses a biological treatment. This statement is supported by McCarty (1964) which said that all forms of inorganic nutrients, $\mathrm{N}$ and $\mathrm{P}$ will be reduced during the process of wastewater degradation using a biological process is normal. Number of biological nutrient needs, $\mathrm{N}$ and $\mathrm{P}$ required by microorganisms is directly proportional to their growth.

\section{CONCLUSION}

The Following conclusions ca be drawn from the present study: (1) the addition of fertilizer as a nutrient, the decreasing process some parameters better than the control which not added anything and (2) Gandasil B fertilizer in the anaerobic reactor improves the rate of organic material degradation more effectively than Gandasil D fertilizer. 


\section{ACKNOWLEDGEMENT}

This research was funded by DIPA Airlangga University 2013. Numbered Letter of Rector Airlangga University 7673/UN3/KR/2013 (May 2, 2013). This research was held by Ms. Nur Indradewi Oktavitri S.T., M.T. This research was supported with solid team: Deavy Trianingtyas; Bidayatus Saadah; Fandi Nufinda Rahman; Hairul Amin; Adelia Anju Asmara; Santini Ika R.; Rosvita Tri J.; Sofiyudin; Defananda Satya A..

\section{REFERENCES}

[1]. Romli, Muhammad and Suprihatin, "Beban Pencemaran Limbah Cair Industri Tahu dan Analisis Alternatif Strategi Pengelolaannya,” Jurnal Purifikasi, vol. 10, No. 2, 2009, pp. 141-154.

[2]. Myrasandri, Puteri and Mindriany Syafila, "Degradasi Senyawa Organik Limbah Cair Tahu dalam Anaerobic Baffled Reactor," Program Studi Teknik Lingkungan, Fakultas Teknik Sipil dan Lingkungan, Institut Teknologi Bandung (ITB), 2010.

[3]. Cakir, Fatma Yasemin and Michael K. Stenstrom, "Anaerobic Treatment of Low Strength Wastewater," Los Angeles: Department of Civil and Environmental Engineering, UCLA, 90095-1593.

[4]. Mc. Carty, Perry L, "Anaerobic Waste Treatment Fundamentals, Part One: Chemistry and Microbiology,” Public Works, Vol. 95, No. 9, 1964, pp. 107-112.

[5]. Maier, RM, "Bacterial Growth, Chapter 3,” In: Maier RM, Pepper IL, Gerba CP (eds). Environmental Microbiology, Academic Press, 1999, pp. 43-59.

[6]. Ammary, Bashaar Y., "Nutrients Requirments in Biological Industrial Wastewater Treatment," African Journal of Biotechnology, Vo. 3 (4), , April 2004, pp. 236-238.

[7]. Lettinga G, “Anaerobic reactor technology,” Lecture notes by Prof. G. Lettinga in International Course on Anaerobic Wastewater Treatment, Wageningen Agriculture University, The Delft, Netherlands, 1995.
[8]. Bagus S., I Nyoman, "Start-up dan Perancangan Bioreaktor Anaerobik Untuk Pengolahan Limbah Cair dengan Konsentrasi Garam Tinggi,” Departemen Teknologi Industri Pertanian, Fakultas Teknologi Pertanian, Intstitut Pertanian Bogor, 2008.

[9]. Nayono, Satoto E. "Metode Pengolahan Air Limbah Alternatif untuk Negara Berkembang,” Technical Review: Jurusan Teknik Sipil dan Perencanaan, Fakultas Teknik, Universitas Negeri Yogyakarta, 2010.

[10]. Paramita P., M. Shovitri, dan N. D. Kuswytasari, "Biodegradasi Limbah Organik Pasar dengan Menggunakan Mikroorganisme Alami Tangki Septik,” J. Sains dan Seni ITS, 2012, Vol. 1, pp. 23-26.

[11]. Zam, Syukria Ikhsan, "Optimasi Konsentrasi Inokulum, Rasio C:N:P dan $\mathrm{pH}$ pada Proses Bioremediasi limbah Pengilangan Minyak Bumi Menggunakan Kultur Campuran,” El-Hayah, Vol. 1, No. 2, Maret 2010, pp. 23-34.

[12]. Setiawan, Yusup, Sri Purwanti, Rina S. Soetopo, dan Kristaufana J.P., "Peningkatan Efektivitas Pengolahan Air Limbah Proses Pemutihan Pulp dengan Reaktor UP-Flow Anaerobic Sludge Blanket (UASB) dan Lumpur Aktif Termobilisasi,” Berita Selulosa, Vo. 43 (2), Desember 2008, pp. 74-82.

[13]. Salimin, Zainus dan Jaka Rachmadetin, "Denitrifikasi Limbah Radioaktif Cair yang Mengandung Asam Nitrat dengan Proses Biooksidasi,” Prosiding Seminar Nasional Teknologi Pengelolaan Limbah IX, Pusat Teknologi Limbah Radioaktif, BATAN, Fakultas Teknik, Universitas Sultan Ageng Tirtayasa, 2011, pp. 149-158.

[14]. Hapsari, Rezka Putri, "Peranan Mikroorganisme dalam Pengolahan Limbah B3,” Teknik Kimia, Institut Teknolog Sepuluh Nopember Surabaya, 2012, pp. 1-16.

[15]. Anonym, "Gandasil D dan Gandasil B Pupuk Foliar Favorit," file://E:/APTECS\%202013/Gandasil\%20D\%20dan\%20Gandasi 1\%20B\%20Pupuk\%20Foliar\%20Favorit\%20\%20\%20Jurnal\%20 Agrikultur.htm. Published On July 7, 2013.

[16]. P.C. Hanlon, editor, "Compressor Handbook", McGraw-Hill, New York, 2001

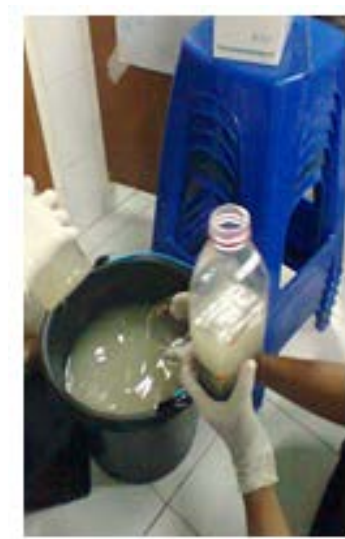

(a)

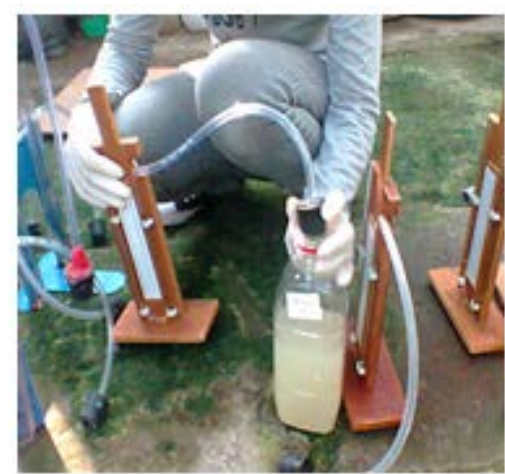

(b)

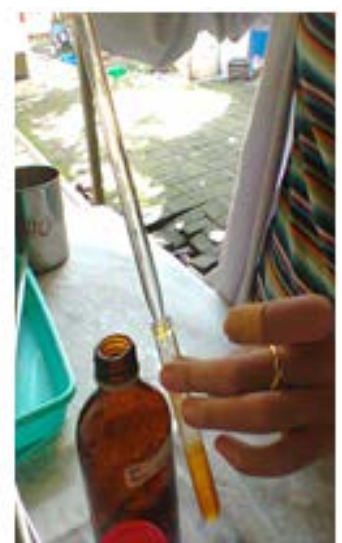

(c)

Figure 1. Some steps on the procedure of research. (a) $600 \mathrm{ml}$ tofu wastewater poured in the plastic bottle. (b) The combine of plastic bottle, hole cap, plastic hose, and manometer. (c). The process of analyze COD (Chemical Oxygen Demand) parameter

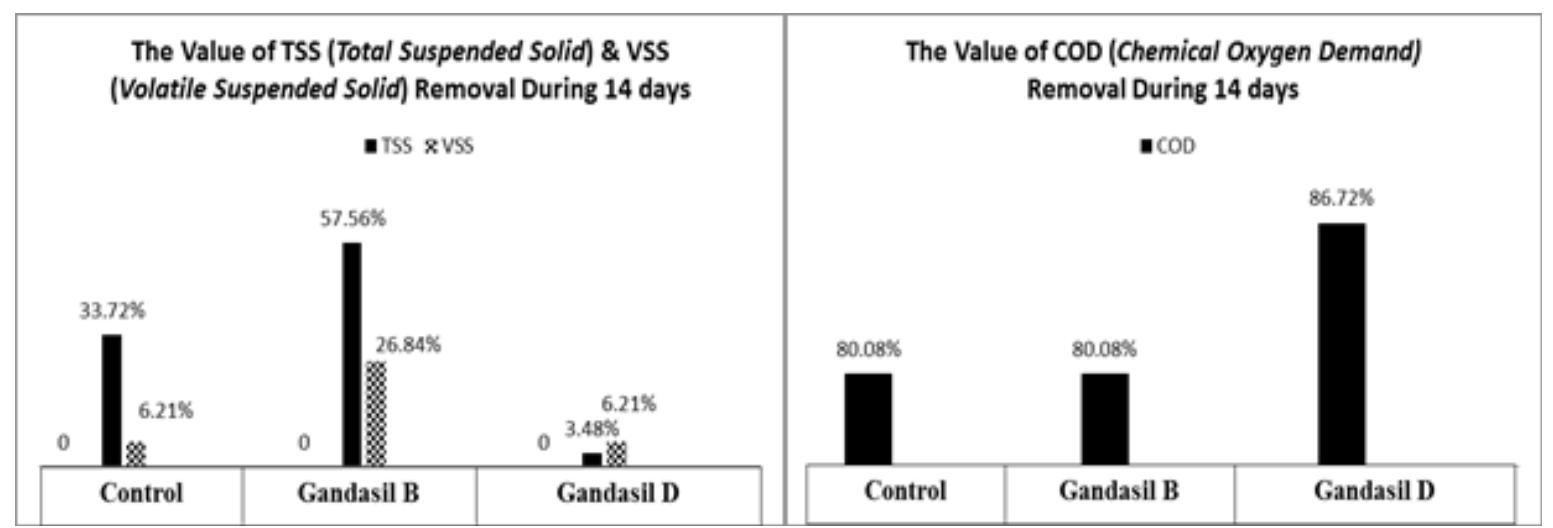

Figure 3. The Value of TSS (Total Suspended Solid), VSS (Volatile Suspended Solid), and COD (Chemical Oxygen Demand) Removal during 14 days 


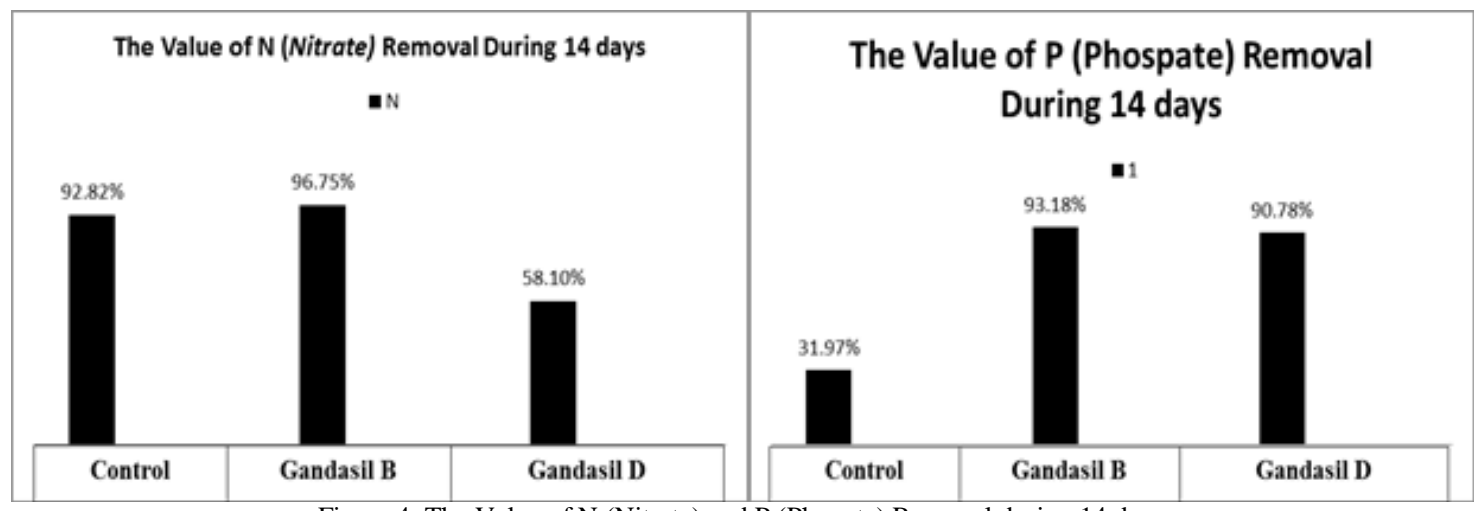

Figure 4. The Value of N (Nitrate) and P (Phopate) Removal during 14 days

TABLE 1.

THE ANALYSIS OF TOFU WASTEWATER'S PARAMETERS

\begin{tabular}{cccccccc}
\hline \hline \multirow{2}{*}{ Parameters } & \multicolumn{2}{c}{ Control } & \multicolumn{2}{c}{ Gandasil B } & \multicolumn{2}{c}{ Gandasil D } & Unit \\
& $\mathbf{0}$ day & $\mathbf{1 4}^{\text {th }}$ day & $\mathbf{0}$ day & $\mathbf{1 4}^{\text {th }}$ day & $\mathbf{0}$ day & $\mathbf{1 4}^{\text {th }} \mathbf{~ d a y ~}$ & \\
\hline TSS & 860 & 570 & 860 & 365 & 860 & 830 & $\mathrm{mg} / \mathrm{L}$ \\
VSS & 483.3 & 453.33 & 453.33 & 331.67 & 483.33 & 453.3 & $\mathrm{mg} / \mathrm{L}$ \\
COD & 10000 & 1992 & 10000 & 1992 & 10000 & 1328 & $\mathrm{mg} / \mathrm{L}$ \\
$\mathrm{N}$ & 4.32 & 0.31 & 4.32 & 0.14 & 4.32 & 1.81 & $\mathrm{mg} / \mathrm{L}$ \\
$\mathrm{P}$ & 221.43 & 150.63 & 221.43 & 15.1 & 221.43 & 20.42 & $\mathrm{mg} / \mathrm{L}$ \\
\hline \hline
\end{tabular}

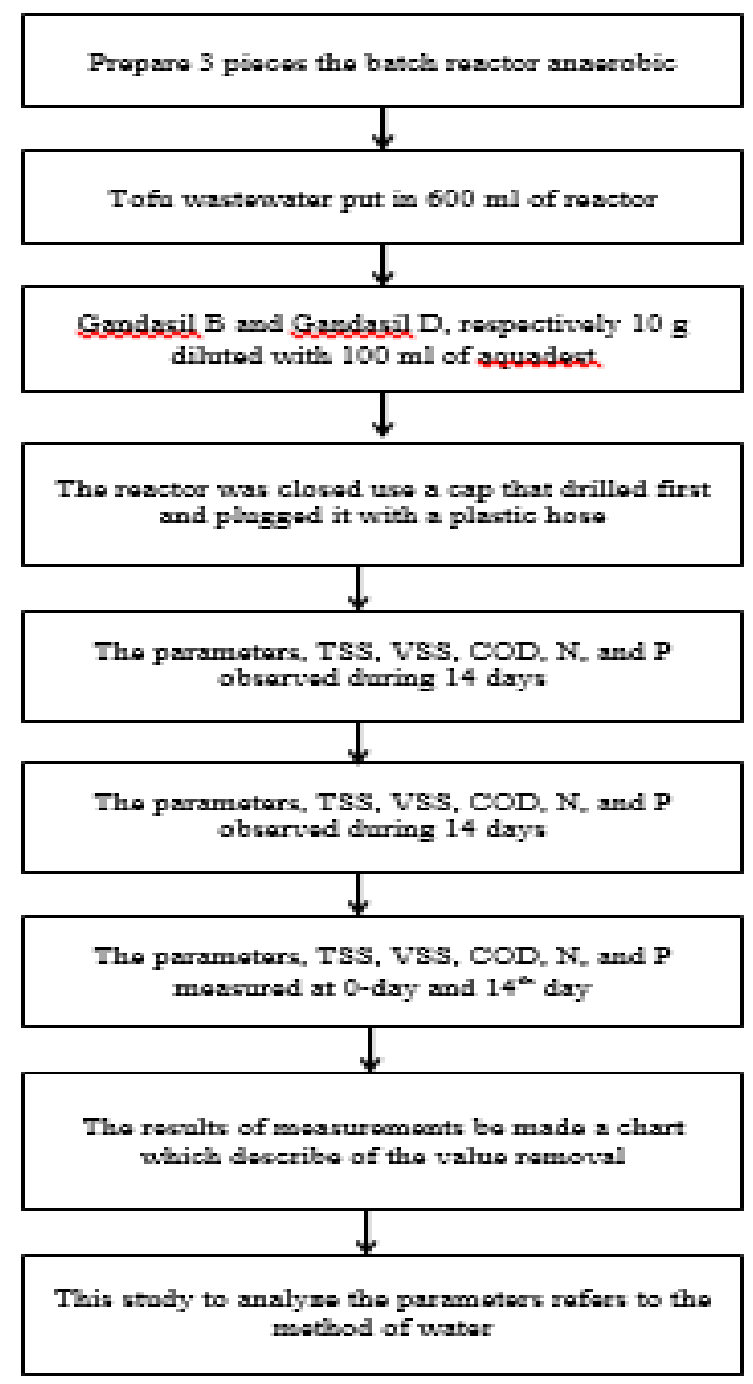

Figerc. 2 The step of procedure this rasourch 